\title{
Comparison of extensive and intensive pig production systems in Uruguay in terms of ethologic, physiologic and meat quality parameters
}

\author{
Oscar Ricardo Blumetto Velazco ${ }^{1}$, Salvador Calvet Sanz², Fernando Estellés Barber², \\ Arantxa Villagrá García ${ }^{3}$
}

\footnotetext{
${ }^{1}$ Instituto Nacional de Investigación Agropecuaria (INIA), Estación Experimental Las Brujas, Uruguay.

${ }^{2}$ Instituto de Ciencia Animal y Tecnología, Universitat Politècnica de València, España.

${ }^{3}$ Centro de Investigación y Tecnología Animal (CITA-IVIA), València, España.
}

\begin{abstract}
The objective of this work is to characterize two contrasting systems of fattening pigs in Uruguay. A total of 96 pigs (average $41.7 \mathrm{~kg}$ ) were divided into eight groups of 12 animals, representing two production systems: (IN) pigs confined in pens of $12 \mathrm{~m}^{2}$ or (OUT) kept in plots with field shelters and access to pasture. Behavioral observations were performed by scan sampling at 5-minute intervals, three times a day during weeks 6, 8, 10 and 12 of the experiment. Aggressions were also observed at the end of the experimental period. Blood samples were taken for cortisol analysis and other physiological parameters, during growth period and slaughter and meat quality characteristics were assessed after slaughter. Differences were found in carcass characteristics, wherein IN presented a higher dorsal fat. These animals presented an overall lower activity and spent less time resting, with a stable pattern throughout the day. In OUT, pigs usually rested at midday hours, more active in the morning and afternoon. The number of total reciprocal aggressions in the observation period was $4.2 \pm 3.7$ for IN and $2.3 \pm 2.2$ for OUT. Cortisol levels and biochemical profile did not show evidence of important problems in the animals. Welfare is not compromised in any of the systems, although higher levels of cortisol and aggressions could be indicating some stress problems in the confinement system. Meat characteristics in OUT were considered better than in IN from a nutritional point of view.
\end{abstract}

Key Words: aggressions, behaviour, housed pig, outdoor pig, pasture

\section{Introduction}

More than $60 \%$ of pigs are reared outdoors in Uruguay, with variable participation of pastures in feed (DIEA, 2007). Outdoor production systems with pastures are becoming attractive for consumers, mainly due to environmental sustainability and social benefits of the sector as well as the initial low cost of the production system (Leite et al., 2001). In addition, outdoor rotation systems have been reported to be of interest in South America because they have been adopted by small and medium farmers (Leite et al., 2006). Other characteristics of these production systems, which affect animal welfare and product quality, have a growing societal and scientific importance (Smulders et al., 2006). Pigs produced under outdoor conditions present different meat characteristics mainly due to exercise (Daza et al., 2009) or to pasture intake (Moisá et al., 2007), and these may affect pH (Bee et al., 2004), fat deposition (Gentry et al., 2002), fatty acid profile (Daza et al., 2009) or meat colour (Echenique et al., 2009).

Several aspects of behaviour have been used to evaluate confinement effects or to compare it with outdoor systems.
Some examples are negative (Barnett et al., 1993; Deen, 2010) and positive (Temple et al., 2011) social behaviour, exploratory behaviour (Beattie et al., 2000; Docking et al., 2008), development of abnormal behaviour (Lawrence \& Terlouw, 1993; Moinard et al., 2003) or resting time (Scott et al., 2006), among others. On the other hand, changes in behavioural patterns often represent the first level of response of an animal to an aversive or stressful environment (Temple et al., 2011). Furthermore, there are other behavioural and physiological responses commonly used to measure animal welfare (Barnett, 2007) such as animal health (Broom, 2006) or serum biochemical profile (Chorfi et al., 2007; Adams et al., 2008). Cortisol is the most widely used physiological parameter because of its association with stress and acute stressors (Barnett et al., 1996; Rushen et al., 1995) or because of a permanent social stress in animals reared in poor environments (de Jonge et al., 1996). However, assessment of stress must be based on a wide range of variables describing the process (Jensen et al., 2004).

The main objective of the present work is to compare two contrasting systems of fattening pigs, one with 
animals confined in pens and an alternative outdoor system with rotational pasture access. This study is focused on productivity, meat quality characteristics, animal behaviour and physiological stress indicators.

\section{Material and Methods}

Two trials were carried out at Las Brujas Experimental Centre of the National Agricultural Research Institute (INIA) of Uruguay. The experimental period lasted 12 weeks, from October 23th 2007 to January 16th 2008. Ninety-six Landrace $\times$ Large Withe pigs of 12 weeks of age and $41.7 \pm 5.81 \mathrm{~kg}$ average live weight (48 females and 48 castrated males) were used. Animals were individually tagged and randomly divided into eight groups of six females and six males each. Four groups were assigned to a conventional indoor confined fattening system (IN), and the rest to an outdoor system with free access to grassland plots (OUT).

In IN, pigs were housed in a natural-ventilation building, in $4 \times 3 \mathrm{~m}$ pens. Floor surface was $25 \%$ plastic slat and $75 \%$ solid concrete. In OUT, each group was housed in a $20 \times 10 \mathrm{~m}$ yard (permanent plot), with a $12 \mathrm{~m}^{2}$ wood hut. Ten different $170 \mathrm{~m}^{2}$ grassland plots were built and every week, each group had free access to one of these grazing plots. After this week, a new plot was opened and the old one was closed in order to provide the animals with fresh pasture and avoid over-pasturing. This process was followed according to the order shown in Figure 1.

In all groups, animals were fed ad libitum with the same commercial concentrate, with nutrient contents of $88.9 \%$ dry matter (DM) and $14.9 \%$ crude protein (CP), $13.2 \%$ acid detergent fiber (ADF), 34\% neutral detergent fiber (NDF), $3.98 \%$ ether extract (EE) and $4.7 \%$ o f ash on a dry matter basis. Pasture in OUT was a seeded prairie with a mix of white clover, red clover and ryegrass.

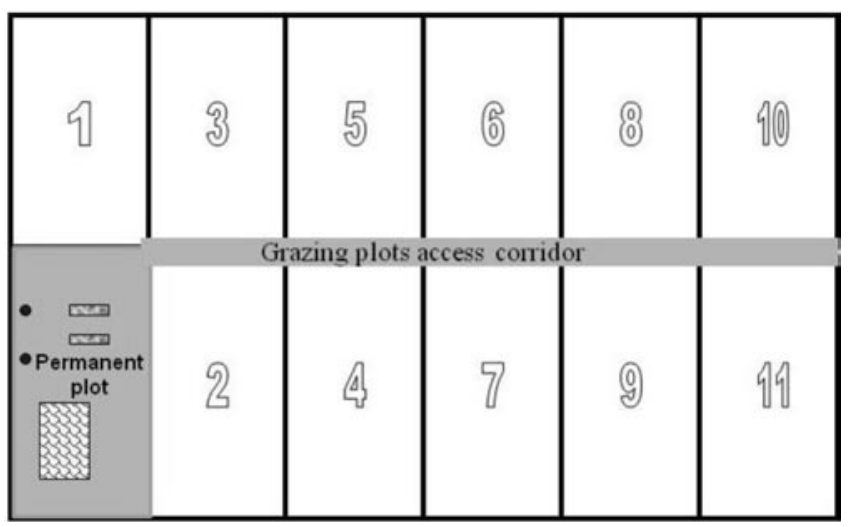

Figure 1 - Housing diagram and distribution of grazing plots in treatment OUT.
Individual live weight and group feed intake were measured weekly. Pasture intake was calculated by the difference between initial availability and remaining pasture at the end of the seven-day grazing period with standard method (Moliterno, 1997). Pasture samples were taken at the moment of opening the new plots and after closing. Average feed conversion rate per group was estimated by dividing weekly feed intake and the sum of weekly individual live weight gain.

Animals were slaughtered at 169 days of age, after 2 hours transport and 6 hours of lairage in a unique paddock. Twenty-four animals per treatment (six animals per group) were selected for carcass and meat studies as described by Gispert et al. (2007). Carcass length, pH 45 min postmortem, dorsal fat thickness ( $\mathrm{mm}$ ) at the gluteus medium, dorsal fat thickness $(\mathrm{mm})$ at the last rib and $\mathrm{pH} 24$ hours post-mortem ( $\mathrm{pH} 24)$ were recorded at the slaughterhouse. Muscle colour was measured in loin eye at the first steak level, with a Minolta C10 colorimeter, determining parameters $\mathrm{L}^{*}$ (lightness), $\mathrm{a}^{*}$ (redness/greenness) and $\mathrm{b}^{*}$ (yellowness/blueness). Chroma (C) and Hue angle $\left(\mathrm{H}^{\circ}\right)$ values were obtained by the following equations:

$$
C=\left(a^{* 2}+b^{* 2}\right)^{0.5} ; H^{0}=\operatorname{arctg} b * / a *
$$

Fat samples for fatty acid analysis were collected from the same animals as dorsal fat at the last rib. This lipid profile was analysed by liquid chromatography at the Nutrition Laboratory of the Chemistry Faculty of the Republic University (Montevideo, Uruguay), determining individual fatty acid contents, total saturated fatty acids (SFA), total monounsaturated fatty acids (MUFA) and total polyunsaturated fatty acids (PUFA).

Behaviour of outdoor-system pigs (OUT), was directly observed by two observers in three daily periods of two hours (morning: $7 \mathrm{~h} 00$ to $9 \mathrm{~h} 00$; midday: $13 \mathrm{~h} 00$ to $15 \mathrm{~h} 00$; and afternoon: $18 \mathrm{~h} 00$ to $20 \mathrm{~h} 00$ ), on three alternate days a week, during four weeks, $(6,8,10$ and 12). Animals in IN were continuously recorded and behavioural observations were carried out in the same periods (morning: $7 \mathrm{~h} 00$ to 9h00, midday: $13 \mathrm{~h} 00$ to $15 \mathrm{~h} 00$; and afternoon: $18 \mathrm{~h} 00$ to 20h00), on three alternate days a week, in weeks $6,8,10$ and 12 of the experiment. Because of problems in video recordings of weeks 6 and 8 , only weeks 10 and 12 could be used for the analysis. In both treatments, observations were carried out by scan sampling every five minutes, recording the number of pigs performing each of the activities (Table 1). This ethogram was partially adapted from Morgan et al. (1998) and Bolhuis et al. (2005).

In addition, active and passive behaviour rates were created by integrating active behaviours (eating, drinking, 
Table 1 - Description of recorded behaviour

\begin{tabular}{lc}
\hline Behaviour & Description \\
\hline Eating (EC) & Animal with the head in the feed trough or chewing concentrate. \\
Drinking (D) & Animal with its mouth on drinking nipple. \\
Grazing (G) & Animal with its head in vegetation or chewing pasture. \\
Walking (W) & Animal moving without another distinguished behaviour (exploring, grazing, etc.). \\
Exploring (E) & Smelling, touching with nose, or rooting any material, floor or infrastructure. \\
Hut (H) & Animal staying inside the hut. \\
Resting (R) & Animals with body recumbent on sternum or side, or sitting without exploring behaviour. \\
Mud resting (M) & Animal resting in the mud. \\
Interaction (I) & Animal fighting or playing with physical contact. \\
Others (O) & Other behaviours than those described above. \\
\hline
\end{tabular}

grazing, walking, exploring, interacting and others) and passive behaviours (staying in the hut, resting and resting in the mud). Considering that the resting behaviour of outdoor pigs was mainly developed inside the huts, a variable was created in order to compare resting behaviour of IN in relation to OUT. This variable (TR) resulted from integrating $\mathrm{R}$ and $\mathrm{H}$ for OUT, while for IN it was considered that $\mathrm{TR}=\mathrm{R}$.

Agonistic behaviour (aggressions) was separately recorded in IN and OUT during weeks 11 and 12 every two days. Two observers recorded aggressions between animals by continuous observation in two 30-minute periods: one in the morning (randomly for each group between $9 \mathrm{~h} 00$ and 10h00), and another in the afternoon (randomly between $18 \mathrm{~h} 00$ and 19h00). Three levels of aggressions were established: aggression of one animal on another without response (unidirectional aggression), aggression of one animal on another with response (reciprocal aggression) and fight, which was described as a reciprocal aggression during at least five seconds. In all observations, the activity performed by the pigs at the moment of the aggression was also recorded.

Blood samples of six randomly selected pigs of each group (a total of 24 animals per treatment) were taken on day 84 of the experiment, during the weighing routine, for the two treatments and in the slaughterhouse at the moment animals were stuck after electric stunning. Samples were collected in $7 \mathrm{~mL}$ vacuum tubes without anticoagulant and immediately refrigerated and taken to the laboratory, where they were centrifuged at $3000 \mathrm{rpm}$ for $15 \mathrm{~min}$ at $4{ }^{\circ} \mathrm{C}$, as described by Titto et al. (2010). Serum was then removed and transferred to eppendorf tubes $(1.5 \mathrm{~mL})$ for storage at $-40{ }^{\circ} \mathrm{C}$ until the analyses were performed. Serum samples were assayed in the Laboratory of Nuclear Techniques, Veterinary Faculty, (Montevideo, Uruguay). Cortisol concentrations were determined by a direct solid-phase radioimmunoassay (RIA) using DPC kits (Diagnostic Product Co., Los Angeles, CA, USA).
The RIA had a sensitivity of $0.52 \mu \mathrm{g} / \mathrm{dL}$. All samples were determined in the same assay. The intra-assay coefficients of variation for low $(1.28 \mathrm{ug} / \mathrm{dL})$, medium $(5.91 \mathrm{ug} / \mathrm{dL})$ and high concentration $(17.05 \mathrm{ug} / \mathrm{dL})$ ranges were 10.89 , 7.13 and $2.58 \%$, respectively.

Finally, thirteen biochemical parameters were determined by IDEXX VetTest ${ }^{\circledR}$ Chemistry Analyzer: creatinine kinase, gamma glutamine transferase, alanine transpherase, glucose, globuline, total protein, alkaline phosphatase, calcium, total bilirubine, urea, creatinine, cholesterol and amylase.

All data were analyzed on SAS (Statistical Analysis System, version 9.2). Live weight and average daily gain were analyzed using procedure Mixed with a repeated measurement design. A General Linear Model procedure was performed for meat characteristics, cortisol concentration and biochemical blood profile. Logarithmic transformations for cortisol and biochemical profile were used for the analysis.

For general behaviour and aggressions, the statistical unit was the group. Behavioural data were transformed prior to the analysis into relative numbers (proportion of pigs within a group doing each activity; expressed as a mean of the observation period). Treatment effects on each behaviour were evaluated using procedure mixed linear models (proc MIXED) with repeated measurement design and a compound symmetry covariance structure. The model included treatment (IN, OUT), period of observation (morning, midday and afternoon) and the interaction between treatment and period as fixed effects. Tukey-Kramer adjustments were made for post-hoc comparisons. Regarding aggressions, data were analyzed by PROC MIXED with repeated measurement design, using treatment and moment of the day as fixed effects. Effects were corrected for multiple testing with TukeyKramer test, with $\mathrm{P} \leq 0.05$ as significance level. Logarithmic transformations for behaviour and aggression data were used as well. 


\section{Results}

No significant differences between the studied systems in final live weight were found, although average weekly weight gain showed significant differences $(\mathrm{P}=0.0126)$ : $5.5 \pm 1.7$ and $5.1 \pm 1.9 \mathrm{~kg}$, for IN and OUT respectively. Moreover, if considering the comparison between treatments for each week separately (Table 2), significant differences $(\mathrm{P}<0.001)$ of weight gain were found only for the third week of the experiment.

As regards average feed intake (Table 3), animals in OUT systems ingested significantly more dry matter than those in IN, adding pasture and concentrate intake. This, along with the lower weekly gain and consequent lower live weights, resulted in a significantly higher conversion rate.

Regarding carcass characteristics (Table 4), dorsal fat thickness was higher in IN than OUT, both at gluteus medium and last rib, whereas no differences were found for the rest of carcass measures. Meat colour did not present significant differences between parameters, except for L, which was higher for IN pigs.

Regarding the fatty acid profile (Table 5), monounsaturated fatty acids (MUFA) and trans acids were significantly higher in IN, while polyunsaturated fatty

Table 2 - Average weekly live weight gain per animal $(\mathrm{kg})$ in indoor traditional system (IN) and outdoor system (OUT)

\begin{tabular}{lccc}
\hline $\begin{array}{l}\text { Week of the } \\
\text { experiment }\end{array}$ & $\begin{array}{c}\mathrm{IN} \\
\text { mean } \pm \text { SD }\end{array}$ & $\begin{array}{c}\text { OUT } \\
\text { mean } \pm \text { SD }\end{array}$ & P-value \\
\hline 1 & $5.16 \pm 1.31$ & $4.49 \pm 1.32$ & $\mathrm{NS}$ \\
2 & $4.47 \pm 1.52$ & $3.63 \pm 1.24$ & $\mathrm{NS}$ \\
3 & $5.17 \pm 1.62$ & $2.73 \pm 1.36$ & $<0.001$ \\
4 & $4.69 \pm 1.69$ & $5.54 \pm 1.72$ & $\mathrm{NS}$ \\
5 & $6.14 \pm 1.71$ & $5.58 \pm 1.57$ & $\mathrm{NS}$ \\
6 & $5.70 \pm 1.64$ & $5.85 \pm 1.28$ & $\mathrm{NS}$ \\
7 & $5.89 \pm 1.62$ & $5.59 \pm 1.18$ & $\mathrm{NS}$ \\
8 & $6.35 \pm 1.69$ & $6.47 \pm 1.44$ & $\mathrm{NS}$ \\
9 & $5.83 \pm 1.81$ & $6.19 \pm 1.40$ & $\mathrm{NS}$ \\
10 & $5.79 \pm 1.64$ & $5.20 \pm 1.60$ & $\mathrm{NS}$ \\
11 & $5.55 \pm 1.59$ & $6.47 \pm 1.92$ & $\mathrm{NS}$ \\
12 & $5.72 \pm 1.85$ & $4.82 \pm 1.82$ & $\mathrm{NS}$ \\
\hline
\end{tabular}

SD - standard deviation; NS - not significant.

Table 3 - Total average feed intake, pasture intake and conversion rate per animal in traditional indoor system (IN) and outdoor system (OUT)

\begin{tabular}{lccc}
\hline & IN & OUT & P-value \\
\hline Average concentrate intake $(\mathrm{kg} \mathrm{DM})$ & 258.12 & 264.5 & $\mathrm{NS}$ \\
Average pasture intake $(\mathrm{kg} \mathrm{DM})$ & - & 21.63 & - \\
Total average intake $(\mathrm{kg} \mathrm{DM})$ & 258.12 & 286.1 & $\mathrm{P}<0.05$ \\
Concentrate conversion rate $(\mathrm{kg} \mathrm{DM} / \mathrm{kg})$ & 3.95 & 4.30 & $\mathrm{P}<0.0001$ \\
Total conversion rate $(\mathrm{kg} \mathrm{DM} / \mathrm{kg})$ & 3.95 & 4.65 & $\mathrm{P}<0.0001$ \\
\hline
\end{tabular}

SD - standard deviation; NS - not significant. acids PUFA were higher in OUT. Nevertheless, individual unsaturated fatty acids showed different patterns according to the type of acid for both treatments. As regards individual monounsaturated fatty acids, only 18:1 showed significant differences, with higher values in IN, while 16:1 and 20:1 did not differ between treatments.

Regarding individual polyunsaturated fatty acids, 18:2 cis and 20:2 showed significant differences between treatments, with higher concentrations in pigs of OUT. Despite the fact that 18:2 trans was significantly higher in IN, values were trace concentrations, tending to zero.

Table 4 - Carcass and meat characteristics of pigs reared in traditional indoor system (IN) and outdoor (OUT) system

\begin{tabular}{lcccc}
\hline & Treatment & IN & OUT & P \\
\hline Canal traits & DFTGM (mm) & $30.7 \pm 7.6$ & $26.9 \pm 6.0$ & 0.0438 \\
& DFTLR (mm) & $33.7 \pm 4.9$ & $29.8 \pm 5.3$ & 0.0045 \\
& Point M (mm) & $75.7 \pm 24.0$ & $74.3 \pm 22.0$ & NS \\
& CL $(\mathrm{mm})$ & $815.6 \pm 20.2$ & $808.4 \pm 19.1$ & $\mathrm{NS}$ \\
& $\mathrm{pH} 45$ & $6.26 \pm 0.3$ & $6.15 \pm 0.4$ & $\mathrm{NS}$ \\
Meat colour & $\mathrm{pH} 24$ & $5.70 \pm 23.0$ & $5.67 \pm 15.0$ & $\mathrm{NS}$ \\
& $\mathrm{L}$ & $50.41 \pm 2.7$ & $48.12 \pm 3.5$ & 0.0339 \\
& $\mathrm{a}$ & $7.33 \pm 2.1$ & $7.49 \pm 2.1$ & $\mathrm{NS}$ \\
& $\mathrm{b}$ & $11.18 \pm 1.5$ & $10.61 \pm 1.8$ & $\mathrm{NS}$ \\
& Chroma & $13.4 \pm 2.33$ & $13 \pm 2.61$ & $\mathrm{NS}$ \\
& Hue & $57.34 \pm 4.64$ & $55.3 \pm 3.28$ & $\mathrm{NS}$ \\
\hline DFTGM - dorsal fat thickness (in mm) at the gluteus medium; DFTLR - dorsal fat
\end{tabular}

DFTGM - dorsal fat thickness (in mm) at the gluteus medium; DFTLR - dorsal fat thickness (in mm) at the last rib; CL - carcass length; NS - not significant.

Table 5 - Fatty acid composition (\% of total fat) of back fat in pigs reared in traditional indoor (IN) or outdoor (OUT) systems

\begin{tabular}{lccc}
\hline Fatty acids & IN & OUT & P-value \\
\hline $14: 0$ & $1.17 \pm 0.12$ & $1.15 \pm 0.16$ & $\mathrm{NS}$ \\
$16: 0$ & $23.16 \pm 1.33$ & $22.77 \pm 1.26$ & $\mathrm{NS}$ \\
$16: 1$ cis & $1.48 \pm 0.21$ & $1.47 \pm 0.23$ & $\mathrm{NS}$ \\
$17: 0$ & $0.55 \pm 0.14$ & $0.39 \pm 0.07$ & $<0.0001$ \\
$18: 0$ & $12.57 \pm 1.70$ & $12.43 \pm 1.21$ & $\mathrm{NS}$ \\
$18: 1$ trans & $0.19 \pm 0.06$ & $0.11 \pm 0.04$ & 0.0065 \\
$18: 1$ cis & $41.79 \pm 1.56$ & $40.46 \pm 1.54$ & 0.004 \\
$18: 2$ trans & $0.01 \pm 0.03$ & $0.00 \pm 0.00$ & 0.048 \\
$18: 2$ cis & $14.88 \pm 1.66$ & $16.86 \pm 2.04$ & 0.0002 \\
$20: 0$ & $0.20 \pm 0.04$ & $0.20 \pm 0.02$ & $\mathrm{NS}$ \\
$20: 1$ cis & $0.62 \pm 0.09$ & $0.6 \pm 0.09$ & $\mathrm{NS}$ \\
$18: 3$ cis & $0.82 \pm 0.11$ & $0.99 \pm 0.14$ & $<0.0001$ \\
$20: 2$ cis & $0.54 \pm 0.06$ & $0.59 \pm 0.08$ & 0.0328 \\
$20: 3$ cis & $0.10 \pm 0.02$ & $0.09 \pm 0.00$ & $\mathrm{NS}$ \\
$20: 4$ cis & $0.21 \pm 0.03$ & $0.23 \pm 0.05$ & $\mathrm{NS}$ \\
$\Sigma$ Saturated (SFA) & $37.64 \pm 2.84$ & $36.91 \pm 1.93$ & $\mathrm{NS}$ \\
$\Sigma$ Monounsaturated (MUFA) & $43.89 \pm 1.65$ & $42.53 \pm 1.59$ & 0.0045 \\
$\Sigma$ Polyunsaturated (PUFA) & $16.56 \pm 1.81$ & $18.76 \pm 2.22$ & 0.0001 \\
PUFA:SFA & $0.44 \pm 0.08$ & $0.51 \pm 0.08$ & 0.0049 \\
MUFA:SFA & $1.16 \pm 0.13$ & $1.17 \pm 0.08$ & $\mathrm{NS}$ \\
n-3 & $0.92 \pm 0.11$ & $1.10 \pm 0.14$ & $<0.0001$ \\
n-6 & $15.39 \pm 1.69$ & $17.48 \pm 2.07$ & 0.004 \\
n-6:n-3 & $16.75 \pm 0.90$ & $15.92 \pm 0.79$ & 0.014 \\
$\Sigma$ Trans & $0.16 \pm 0.08$ & $0.11 \pm 0.04$ & 0.0027 \\
\hline NS - a s sifa & & &
\end{tabular}

NS - not significant. 
Considering saturated individual fatty acids, 17:0 was higher in IN, but no significant differences were found for the rest. In addition, although no differences were found for MUFA:SFA ratio, OUT presented a higher PUFA:SFA ratio and n-3 and n-6 fatty acid levels, but a lower n-6:n-3 ratio.

Active behavior was significantly higher in OUT than in IN and did not differ between the different periods of the day in IN (Table 6). However, activity in OUT was higher in the morning and afternoon in relation to midday, when it reduced to the minimum. Consequently, the opposite tendency was found for passive behavior.

In general, statistically significant differences were present in all the studied behaviours. Eating showed similar results between treatments during the morning and the afternoon, but this behaviour was drastically reduced in OUT during midday period. On the contrary, "walking" was always higher in the outdoor treatment except during midday. At the same time, "grazing" did not appear in the midday period and the use of the huts significantly increased in the same period. However, mud resting was increased in the afternoon. On average, most of the animals of IN were resting during the three periods, and TR was higher in IN in relation to OUT except for midday period.

Regarding agonistic behaviour (Table 5), even though no significant difference was found in general for most of the aggressions studied, a marked tendency to increase

Table 6 - General behaviour of fattening pigs reared indoors (IN) and outdoors (OUT)

\begin{tabular}{|c|c|c|c|c|c|c|c|}
\hline & \multicolumn{2}{|c|}{ Morning } & \multicolumn{2}{|c|}{ Midday } & \multicolumn{2}{|c|}{ Afternoon } & \multirow{2}{*}{ P-value } \\
\hline & IN & OUT & IN & OUT & IN & OUT & \\
\hline $\bar{G}$ & -- & $0.25 \pm 0.15 \mathrm{a}$ & -- & $0.00 \pm 0.00 \mathrm{~b}$ & -- & $0.22 \pm 0.15 a$ & $<0.0001$ \\
\hline $\mathrm{EC}$ & $0.08 \pm 0.02 b$ & $0.08 \pm 0.04 b$ & $0.08 \pm 0.03 b$ & $0.01 \pm 0.01 \mathrm{c}$ & $0.07 \pm 0.01 \mathrm{~b}$ & $0.12 \pm 0.04 \mathrm{a}$ & $<0.0001$ \\
\hline $\mathrm{D}$ & $0.02 \pm 0.01 \mathrm{~b}$ & $0.01 \pm 0.01 \mathrm{c}$ & $0.03 \pm 0.02 \mathrm{a}$ & $0.01 \pm 0.01 \mathrm{c}$ & $0.02 \pm 0.01 \mathrm{~b}$ & $0.03 \pm 0.01 \mathrm{a}$ & $<0.0001$ \\
\hline $\mathrm{W}$ & $0.01 \pm 0.01 \mathrm{~b}$ & $0.06 \pm 0.04 \mathrm{a}$ & $0.01 \pm 0.01 \mathrm{~b}$ & $0.01 \pm 0.01 \mathrm{~b}$ & $0.01 \pm 0.01 \mathrm{~b}$ & $0.05 \pm 0.03 \mathrm{a}$ & $<0.0001$ \\
\hline $\mathrm{E}$ & $0.15 \pm 0.05 \mathrm{a}$ & $0.13 \pm 0.10 \mathrm{a}$ & $0.11 \pm 0.05 b$ & $0.01 \pm 0.02 \mathrm{~d}$ & $0.10 \pm 0.05 b$ & $0.07 \pm 0.06 \mathrm{c}$ & $<0.0001$ \\
\hline $\mathrm{R}$ & $0.71 \pm 0.05 \mathrm{c}$ & $0.17 \pm 0.17 b$ & $0.75 \pm 0.08 \mathrm{c}$ & $0.06 \pm 0.06 \mathrm{a}$ & $0.78 \pm 0.06 \mathrm{c}$ & $0.15 \pm 0.09 b$ & 0.0011 \\
\hline $\mathrm{H}$ & -- & $0.28 \pm 0.19 b$ & -- & $0.90 \pm 0.08 \mathrm{a}$ & -- & $0.27 \pm 0.13 b$ & 0.004 \\
\hline M & -- & $0.01 \pm 0.01 \mathrm{~b}$ & -- & $0.01 \pm 0.01 \mathrm{~b}$ & -- & $0.07 \pm 0.08 \mathrm{a}$ & $<0.0001$ \\
\hline TR & $0.71 \pm 0.05 \mathrm{c}$ & $0.45 \pm 0.19 \mathrm{~d}$ & $0.75 \pm 0.08 b$ & $0.96 \pm 0.04 \mathrm{a}$ & $0.78 \pm 0.06 \mathrm{~b}$ & $0.42 \pm 0.15 \mathrm{~d}$ & $<0.0001$ \\
\hline $\mathrm{A}$ & $0.27 \pm 0.06 \mathrm{~b}$ & $0.54 \pm 0.19 \mathrm{a}$ & $0.25 \pm 0.07 b$ & $0.03 \pm 0.03 \mathrm{~d}$ & $0.22 \pm 0.06 \mathrm{c}$ & $0.50 \pm 0.17 \mathrm{a}$ & $<0.0001$ \\
\hline $\mathrm{P}$ & $0.72 \pm 0.05 \mathrm{c}$ & $0.46 \pm 0.19 \mathrm{~d}$ & $0.75 \pm 0.08 b$ & $0.97 \pm 0.03 \mathrm{a}$ & $0.78 \pm 0.06 \mathrm{~b}$ & $0.50 \pm 0.17 \mathrm{~d}$ & $<0.0001$ \\
\hline
\end{tabular}

EC - eating; D - drinking; G - grazing ; W - walking; E - exploring; H - hut; R - resting; M - mud resting; TR - total resting; A - total active behaviour; P - total passive behaviour. ${ }^{1}$ Means \pm standard deviation of proportion time for each activity in each observation period.

Values with equal letters in the row did not differ statistically $(\mathrm{P}>0.05)$.

Table 7 - Average number of aggressions in each activity during 30-minute observation periods in the morning (AM) and in the afternoon (PM), for pigs reared indoors (IN) and outdoors (OUT) ${ }^{1}$

\begin{tabular}{|c|c|c|c|c|c|c|c|c|c|c|}
\hline & \multirow{2}{*}{ Act } & \multicolumn{3}{|c|}{ Unidirectional aggression } & \multicolumn{3}{|c|}{ Reciprocal aggression } & \multicolumn{3}{|c|}{ Fighting } \\
\hline & & IN & OUT & $\mathrm{P}$-value & IN & OUT & P-value & IN & OUT & P-value \\
\hline \multirow[t]{10}{*}{$\mathrm{AM}$} & $\mathrm{EC}$ & $2.0 \pm 2.5$ & $0.9 \pm 2.0$ & NS & $0.7 \pm 1.3$ & $0.2 \pm 0.5$ & NS & $0.1 \pm 0.3$ & $0.0 \pm 0.0$ & NS \\
\hline & D & $0.4 \pm 0.8$ & $0.6 \pm 1.1$ & NS & $0.4 \pm 1.0$ & $0.5 \pm 1.0$ & NS & $0.0 \pm 0.0$ & $0.1 \pm 0.3$ & $\mathrm{NS}$ \\
\hline & $\mathrm{E}$ & $1.1 \pm 1.7$ & $0.8 \pm 1.9$ & NS & $1.6 \pm 2.3$ & $0.2 \pm 0.8$ & $<0.001$ & $0.2 \pm$ & $0.0 \pm 0.2$ & 0.035 \\
\hline & $\mathrm{R}$ & $1.9 \pm 2.1$ & $1.7 \pm 2.6$ & NS & $0.9 \pm 1.3$ & $0.9 \pm 1.0$ & $\mathrm{NS}$ & $0.1 \pm 0.5$ & $0.2 \pm$ & $\mathrm{NS}$ \\
\hline & $\mathrm{G}$ & --- & $0.0 \pm 0.0$ & --- & --- & $0.0 \pm 0.0$ & --- & --- & $0.0 \pm 0.0$ & --- \\
\hline & M & --- & $0.4 \pm 0.8$ & --- & --- & $0.1 \pm 0.4$ & --- & --- & $0.0 \pm 0.2$ & --- \\
\hline & $\mathrm{O}$ & $0.4 \pm 1.1$ & $0.1 \pm 0.3$ & $\mathrm{NS}$ & $0.1 \pm 0.0$ & $0.0 \pm 0.3$ & NS & $0.0 \pm 0.0$ & $0.0 \pm 0.0$ & NS \\
\hline & A & $3.9 \pm 3.8$ & $2.3 \pm 3.1$ & NS & $2.8 \pm 3.3$ & $1.0 \pm 1.6$ & 0.009 & $0.3 \pm 0.6$ & $0.1 \pm 0.3$ & $\mathrm{NS}$ \\
\hline & $\mathrm{P}$ & $1.9 \pm 2.6$ & $2.1 \pm 2.3$ & NS & $0.9 \pm 1.3$ & $1.0 \pm 1.0$ & NS & $0.1 \pm 0.3$ & $0.2 \pm 0.6$ & NS \\
\hline & Total & $5.8 \pm 5.4$ & $4.4 \pm 3.8$ & NS & $3.7 \pm 3.6$ & $1.9 \pm 1.8$ & NS & $0.4 \pm 0.7$ & $0.3 \pm 0.7$ & NS \\
\hline \multirow[t]{10}{*}{ PM } & $\mathrm{EC}$ & $2.5 \pm 3.1$ & $3.0 \pm 4.6$ & NS & $1.8 \pm 2.2$ & $1.0 \pm 1.5$ & NS & $0.1 \pm 0.3$ & $0.0 \pm 0.0$ & 0.008 \\
\hline & D & $1.4 \pm 3.1$ & $0.8 \pm 1.3$ & NS & $0.4 \pm 0.7$ & $0.4 \pm 0.9$ & NS & $0.0 \pm 0.2$ & $0.0 \pm 0.0$ & NS \\
\hline & $\mathrm{E}$ & $2.5 \pm 2.3$ & $0.2 \pm 0.5$ & $<0.001$ & $1.3 \pm 1.9$ & $0.1 \pm 0.4$ & $<0.001$ & $0.5 \pm 1.2$ & $0.0 \pm 0.0$ & $<0.001$ \\
\hline & $\mathrm{R}$ & $2.6 \pm 1.8$ & $0.8 \pm 1.2$ & $<0.001$ & $1.0 \pm 1.2$ & $0.4 \pm 0.9$ & NS & $0.1 \pm 0.3$ & $0.1 \pm 0.3$ & NS \\
\hline & $\mathrm{G}$ & --- & $1.3 \pm 2.1$ & --- & --- & $0.7 \pm 1.4$ & --- & --- & $0.0 \pm 0.2$ & --- \\
\hline & M & --- & $0.4 \pm 0.7$ & --- & --- & $0.1 \pm 0.5$ & --- & --- & $0.0 \pm 0.2$ & --- \\
\hline & $\mathrm{O}$ & $0.8 \pm 1.5$ & $0.0 \pm 0.0$ & $<0.001$ & $0.3 \pm 0.5$ & $0.0 \pm 0.0$ & $<0.001$ & $0.1 \pm 0.3$ & $0.0 \pm 0.0$ & 0.0198 \\
\hline & A & $7.2 \pm 5.5$ & $5.3 \pm 4.9$ & $\mathrm{NS}$ & $3.7 \pm 3.3$ & $2.2 \pm 2.3$ & 0.039 & $0.8 \pm 1.4$ & $0.0 \pm 0.2$ & $<0.001$ \\
\hline & $\mathrm{P}$ & $2.6 \pm 1.8$ & $1.1 \pm 1.6$ & $<0.001$ & $1.0 \pm 1.2$ & $0.5 \pm 0.9$ & $\mathrm{NS}$ & $0.1 \pm 0.3$ & $0.1 \pm 0.3$ & $\mathrm{NS}$ \\
\hline & Total & $9.8 \pm 5.9$ & $6.4 \pm 4.8$ & NS & $4.7 \pm 3.7$ & $2.7 \pm 2.5$ & 0.048 & $0.9 \pm 1.5$ & $0.1 \pm 0.3$ & 0.001 \\
\hline
\end{tabular}

EC - eating; D - drinking; G - grazing; W - walking; E - exploring; H - hut; R - resting; M - mud resting; I - interaction; O - other. 
Table 8 - Serum cortisol concentration $(\mathrm{ng} / \mathrm{mL}$ ) for pigs reared in two different production systems (IN and OUT) sampled on the 84 th day of the experiment and at slaughter

\begin{tabular}{|c|c|c|c|c|c|}
\hline \multirow{2}{*}{ Treatment } & \multicolumn{2}{|c|}{ IN } & \multicolumn{2}{|c|}{ OUT } & \multirow{2}{*}{ P-valuc } \\
\hline & Range & Mean & Range & Mean & \\
\hline Day 84 & $4.9-7.1$ & 6.0 & $3.4-5.6$ & 4.5 & 0.0167 \\
\hline
\end{tabular}

For the ranges: Upper limit $=\operatorname{Exp}(\mu \ln [$ cortisol concentration] $+\mathrm{SE} \ln [$ cortisol concentration] $)$.

Lower limit $=\operatorname{Exp}(\mu \ln [$ cortisol concentration $)-S E \ln [$ cortisol concentration] $)$.

aggressive behaviour was observed for confined animals as compared with pigs in outdoor system. In this way, reciprocal aggression and fighting were significantly higher in IN.

On the other hand, aggressions were higher during the afternoon than during the morning, although fighting was more stable. This occurred mostly in association with an increase of agonistic behaviour during resting and exploration (Table 7). When the total number of aggressions in active or passive activities is analyzed, it can be observed that in the afternoon, unidirectional aggressions are higher in passive behaviours, while reciprocal and fighting aggressions are mainly produced during active behaviours, always higher in IN. In addition, aggressions while exploring ( $E$ in Table 7) showed significant differences between treatments regardless of the period, always higher in IN as well.

Finally, significant differences were detected for serum cortisol concentrations between IN and OUT $(\mathrm{P}<0.001)$ (Table 8), and levels were higher for IN both on day 84 and at the slaughterhouse.

As regards biochemical profile, most of the parameters analysed were within the reference ranges (Iddex, 2006), except for alanine trasnpherase, cholesterol, gamma glutamine transferase and total protein. Overall, there was not a clear alteration pattern, although OUT resulted in a higher activity of gamma glutamine transferase $(63.7 \pm 21.3$ vs. $48.9 \pm 19 ; \mathrm{P}=0.0327)$ and $\mathrm{IN}$, in a higher activity of glucose $(150.6 \pm 12$ vs. $123.1 \pm 27.2, \mathrm{P}>0.0001)$.

\section{Discussion}

Productive results showed differences between systems not only as to growing rates, but also characteristics linked to the product quality. The reduction in growing rates in outdoor pigs is probably caused by the exercise, which has an extra energy cost (Edwards, 2005), as hypothesized by Hansen et al. (2006) and Bee et al. (2004), although they remarked that it is not possible to separate the effect of increased activity and the effect of the environment in outdoor systems. Regarding this, general live weight evolution was strongly marked by a dramatic reduction of weight gain in OUT during the third week. In this week, several days of cold and hard wind affected outdoor animals, causing a deficient growing response. Long exposures to cold temperatures cause pigs to adapt by reducing energy losses and adjusting intake (Demo et al., 1995; Macari et al., 1986), but when low temperatures occur suddenly or cyclically, animals are more severely affected (Nienaber et al., 1989; Geers et al., 1987). Moreover, higher consumption levels and consequently higher conversion rate reached in OUT could compromise profit of this system and should be studied accurately.

Regarding carcass and meat quality, differences between treatments were concentrated in two characteristics: dorsal fat thickness and lightness of the meat. The reduction of back fat deposition in outdoor systems can be a consequence of exercise, as Enfält et al. (1997) and Gnanaraj et al. (2002) reported, although other authors did not find any difference in fat deposition between systems with outdoor access (Daza et al., 2009; Hale et al., 1986; Morrison et al., 2007). Low lightness of the meat is a desirable characteristic for reducing paleness of meat, and OUT presented lower values than IN, which is in accordance with Pugliese et al. (2005). These authors attributed this characteristic to a higher level of intramuscular fat, which was not measured in the present experiment. Nevertheless, these findings and the lack of differences among the rest of the studied parameters make it possible to infer that meat is similar in both systems, with a little better colour in OUT pigs.

The fatty acid composition of meat receives a lot of attention in research because of its implications for human health, and pig fat is associated with its concentration in the diet (Raes et al., 2004). For this reason, differences in lipid profile of the two production systems have to be considered as relevant results.

Th higher PUFA contents of the fat in OUT animals could be a consequence of including pasture in the diet, given that pasture is an important source of unsaturated fatty acids, especially linolenic acid (Woods \& Fearon, 2009). In addition, pigs from OUT had higher concentrations of linoleic (18:2), linolenic (18:3) and eicosadienoic (20:2) 
acids, which are the most relevant from the nutritional point of view (Nilzén et al., 2001; Lebret \& Guillard, 2005; Pugliese et al., 2005). On the contrary, higher contents of MUFA in IN are explained by 18:1 fatty acid concentration. Because of the influence of the diet on the fat of pigs (Raes et al., 2004), MUFA was expected to be similar or higher in OUT due to pasture intake, although similar results were found by other authors such as Hansen et al. (2006). This result can be interpreted by the fact that pigs in OUT, which had less total fat than IN according to dorsal fat thickness, had an increase in the proportion of unsaturated acids by decreasing the saturated fatty acid deposition, as concluded by Hansen et al. (2006).

On the other hand, a lower n-6:n-3 fatty acid ratio was observed for OUT. Thus, it is reasonable to think that the pasture intake was enough to reduce $n-6: n-3$ ratio by increasing n-3 fatty acid content in OUT animals. Therefore, according to fatty acids, the influence of the pasture intake on the lipidic profile seems clear.

General activity, assessed in the present study as the average of animals performing an active behaviour, is commonly reported as increasing in pigs reared outdoors, whereas in intensive farming systems animals remain physically inactive most of the time (Daza et al., 2009). Space availability is revealed as a reason to explain this behaviour, but some other factors are probably contributing. Activity in OUT was very low at midday, and it increased in the morning and the afternoon, whereas pigs in IN presented the same proportion of activity for the three periods assessed. To this regard, Leite et al. (2006) and Villagrá et al. (2007) found that pigs in multi-activity pens and rotational systems were active mainly during daytime, and the activities were clearly bimodal with peaks in the morning and in the afternoon. Thus, pigs seem to be more likely to have this circadian behaviour in outdoors systems. Nevertheless, in the present work, the activity pattern is also strongly influenced by sun incidence. As regards this, in midday hours all animals looked for a shade inside or near the hut, and they exposed themselves to sun only in isolated activities like drinking, eating concentrate or mud bath. This could be a sign that animals protect themselves from the sun, adapting their behaviour to the different moments of the day or covering their skin with mud.

Regarding individual active behaviours, grazing and exploring were the most frequent. Exploring behaviour did not differ between IN and OUT in the morning or in the afternoon, which is coincident with other authors (Temple et al., 2011), but this can be related to grazing. Grazing was only possible in OUT system, and it was very frequent. The time used for it was similar to the time spent on total active behaviour in IN system for the periods of morning and afternoon, so although exploring did not display differences between systems, grazing did. Thus, frequencies of exploring and grazing behaviours are related, and their separate observation seems interesting from the behavioural viewpoint.

Considering agonistic behaviour, IN showed a general tendency to increase reciprocal aggressive interactions and fighting along the day, although the unidirectional ones were not significant. Intensive rearing conditions tend to foment competition for resources between pigs, increasing the occurrence and duration of negative social interactions (Temple et al., 2011). Space allowance is one of the possible causes, but OUT also had a much enriched environment which contributed to the reduction of agonistic behaviour, as reported by several authors (Beattie et al., 2000; van de Weerd et al., 2006; Morrison et al., 2007; van de Weerd \& Day, 2009). In addition, the higher level of aggressions in IN while exploring suggests that the competence derived from the lack of space affects all the behaviours. Then, when an individual detected a place of its interest, it competes for exploring it. In addition, in our work there was also an increase in aggressions during the afternoon (hotter period), which also showed an influence of discomfort in agonistic behaviour. Thus, not only barren or poor environments but also climatic conditions can increase aggressions.

Serum cortisol concentration in IN was higher than in OUT, although concentrations found on farm on day 84 in the two treatments were low. On the contrary, cortisol levels in blood samples taken at slaughter, after transport and lairage, increased in both IN and OUT, so pigs experienced stress related to transport and loading regardless of the system.

Similarly, most of the biochemical parameters analyzed were inside the reference values, except for alanine trasnpherase, cholesterol, gamma glutamine transferase (related to hepatic function distortion, Idexx, 2006) and total protein. However, animals did not show any symptoms, and they had a normal growth rate. gamma glutamine transferase had been previously related to maize contaminated with Deoxinivalenol (Döll et al., 2005) but no evidence was present in this study.

Glucose concentration in blood serum was higher in IN, and according to Fernandez et al. (1994), it can be explained by the increasing of aggressive behaviour of pigs. Puppe et al. (1997) also found that levels of glucose increased in piglets with increasing stress and Barnett et al. (1983) found elevated levels of plasma glucose as a response to stress in gilts. These authors assume that an increase in glucose levels is a response to increasing 
glucogenesis, which is caused by increasing corticosteroid. This can also be related to higher cortisol levels in IN, so this could be an evidence of distress in pigs under this treatment. Furthermore, animals in OUT presented reduced glucose levels, which can be associated with exercised pigs and diets with a low energy level (Hale et al., 1986).

\section{Conclusions}

Both indoor and outdoor production systems reached an acceptable productive performance and meat quality, with no relevant health problems detected, although conversion rates in OUT animals should be studied. However, meat characteristics are better in animals reared outdoors than indoors. Animals in outdoor systems are in general more active and present a daily pattern of behaviour with two peaks of activity, whereas confined pigs are more sedentary and have a more stable behavioural pattern along the day. The upholding of cortisol levels in animals reared indoors after loading and transport, as well as the higher level of reciprocal aggressions and fights and the higher level of glucose, could be an evidence of some welfare problems in pigs reared in conventional indoor systems in comparison with open systems.

\section{References}

ADAMS, M.C.; LUO, J.; RAYWARD, D. et al. Selection of a novel direct-fed microbial to enhance weight gain in intensively reared calves. Animal Feed Science and Technology, v.145, n.1-4, p.41-52, 2008.

BARNETT, J.L.; HEMSWORTH, P.H.; HAND, A.M. Effects of chronic stress on some blood parameters in the pig. Applied Animal Ethology, v.9, n.3-4, p.273-277, 1983.

BARNETT, J.L.; CRONIN, G.M.; MCCALLUM, T.H. et al. Effects of pen size/shape and design on aggression when grouping unfamiliar adult pigs. Applied Animal Behaviour Science, v.36, n.2-3, p.111-122, 1993.

BARNETT, J.L.; CRONIN, G.M.; MCCALLUM, T.H. et al. Effects of grouping unfamiliar adult pigs after dark, after treatment with amperozide and by using pens with stalls, on aggression, skin lesions and plasma cortisol concentrations. Applied Animal Behaviour Science, v.50, n.2, p.121-133, 1996.

BARNETT, J.L. Effects of confinement and research needs to underpin welfare standards. Journal of Veterinary Behavior: Clinical Applications and Research, v.2, n.6, p.213-218, 2007.

BEATTIE, V.E.; O'CONNELL, N.E.; MOSS, B.W. Influence of environmental enrichment on the behaviour, performance and meat quality of domestic pigs. Livestock Production Science, v.65, n.1-2, p.71-79, 2000.

BEE, G.; GUEX, G.; HERZOG, W. Free-range rearing of pigs during the winter: Adaptations in muscle fiber characteristics and effects on adipose tissue composition and meat quality traits. Journal of Animal Science, v.82, n.4, p.1206-1218, 2004.

BOLHUIS, J.E.; SCHOUTEN, W.G.P.; SCHRAMA, J.W. et al. Behavioural development of pigs with different coping characteristics in barren and substrate-enriched housing conditions. Applied Animal Behaviour Science, v.93, n.3-4, p.213-228, 2005.
BROOM, D.M. Behaviour and welfare in relation to pathology. Applied Animal Behaviour Science, v.97, n.1, p.73-83, 2006.

CHORFI, Y.; LANEVSCHI, A.; DUPRAS, R. et al. Serum biochemical parameters and embryo production during superovulatory treatment in dairy cattle. Research in Veterinary Science, v.83, n.3, p.318-321, 2007.

DAZA, A.; REY, A.I.; OLIVARES, A. et al. Physical activity-induced alterations on tissue lipid composition and lipid metabolism in fattening pigs. Meat Science, v.81, n.4, p.641-646, 2009.

De JONGE, F.H.; BOKKERS, E.A.M.; SCHOUTEN, W.G.P. et al. Rearing piglets in a poor environment: Developmental aspects of social stress in pigs. Physiology \& Behavior, v.60, n.2, p.389-396, 1996.

DEEN, J. Pigs: Behavior and welfare assessment. In: BREED, M.D; MOORE, J. (Eds.) Encyclopedia of Animal Behavior. Oxford: Academic Press, 2010. p.731-739.

DEMO, M.; JENTSCH, W.; HOFFMANN, L. Effect of long time exposure to different environmental temperatures on heat production of growing pigs. Livestock Production Science, v.43, n.2, p.149-152, 1995.

DIEA. Encuesta Porcina 2006. Caracterización de la situación productiva, tecnológica, comercial y social del sector porcino. FPTA, MGAP-INIA, 170. Montevideo, 2007. p.1-71.

DOCKING, C.M.; VAN DE WEERD, H.A.; DAY, J.E.L. et al. The influence of age on the use of potential enrichment objects and synchronisation of behaviour of pigs. Applied Animal Behaviour Science, v.110, n.3-4, p.244-257, 2008.

DÖLL, S.; GERICKE, S.; DÄNICKE, S. et al. The efficacy of a modified aluminosilicate as a detoxifying agent in Fusarium toxin contaminated maize containing diets for piglets. Journal of Animal Physiology and Animal Nutrition, v.89, n.9-10, p.342-358, 2005.

ECHENIQUE, A.; REPISO, L.; CAPRA, G. Composición química y calidad sensorial de jamones curados provenientes de cerdos alimentados con una dieta rica en ácido oleico y pasturas. INNOTEC n.4, p.28-34. Montevideo: LATU, 2009.

EDWARDS, S.A. Product quality attributes associated with outdoor pig production. Livestock Production, v.94, n.1-2, p.5-14, 2005.

ENFÄLT, A.C.; LUNDSTRÖM, K.; HANSSON, I. et al. Effects of outdoor rearing and sire breed (Duroc or Yorkshire) on carcass composition and sensory and technological meat quality. Meat Science, v.45, n.1, p.1-15, 1997.

FERNANDEZ, X.; MEUNIER-SALAÜN, M.C.; MORMEDE, P. Agonistic behavior, plasma stress hormones, and metabolites in response to dyadic encounters in domestic pigs: Interrelationships and effect of dominance status. Physiology and Behavior, v.56, n.5, p.841-847, 1994.

GEERS, R.; VRANKEN, E.; DE LAET, B. et al. Lasting effects of housing conditions after weaning on feed efficiency and carcass grades of growing-finishing pigs. An analysis of field data. Livestock Production Science, v.16, n.2, p.175-186, 1987.

GENTRY, J.G.; MCGLONE, J.J.; BLANTON, J. et al. Alternative housing systems for pigs: Influences on growth, composition, and pork quality. Journal of Animal Science, v.80, n.7, p.1781-1790, 2002.

GISPERT, M.; FURNOLS, M.; GIL, M. et al. Relationships between carcass quality parameters and genetic types. Meat Science, v.77, n.3, p.397-404, 2007.

GNANARAJ, P.T.; SIVAKUMAT, T.; ARUNACHALAN, S. et al. Effect of excercise on carcass traits and blood of growing finishing pigs. Cheiron, v.31, p.137-139, 2002.

HALE, O.M.; NEWTON, G.L; HAYDON, K.D. Effect of diet and exercise on performance, carcass traits and plasma components of growing-finishing barrows. Journal of Animal Science, v.62, n.3, p.665-671, 1986.

HANSEN, L.L.; CLAUDI-MAGNUSSEN, C.; JENSEN, S.K. et al. Effect of organic pig production systems on performance and meat quality. Meat Science, v.74, n.4, p.605-615, 2006.

IDEXX. (2006). Chemistry description and guide. Vet Test Manual Operator. p.H1-H23. 
JENSEN, K.H.; PEDERSEN, L.J.; NIELSEN, E.K. et al. Intermittent stress in pigs: Effects on behavior, pituitary-adrenocortical axis, growth, and gastric ulceration. Physiology \& Behavior, v.59, n.4-5, p.741-748, 2004.

LAWRENCE, A.B.; TERLOUW, E.M. A review of behavioral factors involved in the development and continued performance of stereotypic behaviors in pigs. Journal of Animal, v.71, n.10, p.2815-2825, 1993.

LEBRET, B.; GUILLARD, A.S. Outdoor rearing of cull sows: Effects on carcass, tissue composition and meat quality. Meat Science, v.70, n.2, p.247-257, 2005.

LEITE, D.M.; DALLA COSTA, O.A.; VARGAS, G.A. et al. Análise econômica do sistema intensivo de suínos criados ao ar livre. Revista Brasileira de Zootecnia, v.30, n.2, p.482-486, 2001.

LEITE, D.M.; ABREU DA SILVA, M.; MEDEIROS, R.B. et al. Comportamento de suínos submetidos a diferentes sistemas de pastejo em pastagem de trevo-branco. Revista Brasileira de Zootecnia, v.35, n.4, p.1774-1779, 2006 (supl.).

MACARI, M.; ZUIM, S.M.F.; SECATO, E.R. et al. Effects of ambient temperature and thyroid hormones on food intake by pigs. Physiology \& Behavior, v.36, n.6, p.1035-1039, 1986.

MOINARD, C.; MENDL, M.; NICOL, C.J. et al. A case control study of on-farm risk factors for tail biting in pigs. Applied Animal Behaviour Science, v.81, n.4, p.333-355, 2003.

MOISÁ, S.; BASSO, L.; BACCI, R. et al. Composición de la grasa intramuscular de carne porcina proveniente de diferentes sistemas de producción. Revista Argentina de Producción Animal, v.27, n.1, p.347-395, 2007.

MOLITERNO, E. Método agronómico. Cangüé, n.9, p.32-36, 1997.

MORGAN, C.A.; DEANS, L.A.; LAWRENCE, A.B. et al. The effects of straw bedding on the feeding and social behaviour of growing pigs fed by means of single-space feeders. Applied Animal Behaviour Science, v.58, n.1-2, p.23-33, 1998.

MORRISON, R.S.; JOHNSTON, L.J.; HILBRANDS, A.M. The behaviour, welfare, growth performance and meat quality of pigs housed in a deep-litter, large group housing system compared to a conventional confinement system. Applied Animal Behaviour Science, v.103, n.1-2, p.12-24, 2007.

NIENABER, J.A.; HAHNA, G.L.; KLEMCKE, H.G. et al. Cyclic temperature effects on growing-finishing swine. Journal of Thermal Biology, v.14, n.4, p.233-237, 1989.

NILZÉN, V.; BABOL, J.; DUTTA, P.C. et al. Free range rearing of pigs with access to pasture grazing effect on fatty acid composition and lipid oxidation products. Meat Science, v.58, n.3, p.267-275, 2001.
PUGliESE, C.; BOZZI, R.; CAMPODONI, G. et al. Performance of Cinta Senese pigs reared outdoors and indoors.: 1. Meat and subcutaneous fat characteristics. Meat Science, v.69, n.3, p.459-464, 2005.

PUPPE, B.; TUCHSCHERER, M.; TUCHSCHERER, A. The effect of housing conditions and social environment immediately after weaning on the agonistic behaviour, neutrophil/lymphocyte ratio and plasma glucose level in pigs. Livestock Production Science, v.48, n.2, p.157-164, 1997.

RAES, K.; DE SMET, S.; DEMEYER, D. Effect of dietary fatty acids on incorporation of long chain polyunsaturated fatty acids and conjugated linoleic acid in lamb, beef and pork meat: a review. Animal Feed Science and Technology, v.113, n.1-4, p.199-221, 2004.

RUSHEN, J.; NAY, T.S.; WRIGHT, L.R. et al. Stress and nursing in the pig: Role of HPA axis and endogenous opioid peptides. Physiology \& Behavior, v.58, n.1, p.43-48, 1995.

SCOTT, K.; CHENNELLS, D.J.; CAMPBELL, F.M. et al. The welfare of finishing pigs in two contrasting housing systems: Fully-slatted versus straw-bedded accommodation. Livestock Science, v.103, n.1-2, p.104-115, 2006.

SMULDERS, D.; VERBEKE, G.; MORMÈDE, P. et al. Validation of a behavioral observation tool to assess pig welfare. Physiology \& Behavior, v.89, n.3, p.438-447, 2006.

TEMPLE, D.; MANTECA, X.; VELARDE, A. et al. Assessment of animal welfare through behavioural parameters in Iberian pigs in intensive and extensive conditions. Applied Animal Behaviour Science, v.131, n.1-2, p.29-39, 2011.

TITTO, E.A.L.; TITTO, C.G.; GATTO, E.G. et al. Reactivity of Nellore steers in two feedlot housing systems and its relationship with plasmatic cortisol. Livestock Science, v.129, n.1-3, p.146-150, 2010.

VAN DE WEERD, H.A.; DOCKING, C.M.; DAY, J.E.L. et al. Effects of species-relevant environmental enrichment on the behaviour and productivity of finishing pigs. Applied Animal Behaviour Science, v.99, n.3-4, p.230-247, 2006.

VAN DE WEERD, H.A.; DAY, J.E.L. A review of environmental enrichment for pigs housed in intensive housing systems. Applied Animal Behaviour Science, v.116, n.1, p.1-20, 2009.

VILLAGRÁ, A.; ALTHAUS, R.L.; LAINEZ, M. et al. Modelling of daily rhythms of behavioural patterns in growing pigs on two commercial farms. Biological Rhythm, v.38, v.5, p.347-354, 2007.

WARRISS, P.D. The welfare of slaughter pigs during transport. Animal Welfare, v.7, n.4, p.365-381, 1998.

WOODS, V.B.; FEARON, A.M. Dietary sources of unsaturated fatty acids for animals and their transfer into meat, milk and eggs: A review. Livestock Science, v.126, n.1-3, p.1-20, 2009. 